\title{
Non-alcoholic fatty liver disease as metabolic consequence of obstructive sleep apnea
}

\author{
Ana Ninić ${ }^{1 *}$, Marija Zdravković ${ }^{2}$, Vojislav Radosavljević ${ }^{3}$, \\ Vera Gardijan ${ }^{3}$, Lidija Memon ${ }^{4}$, Jelena Vekić ${ }^{\text {, }}$ \\ Vesna Spasojević- Kalimanovska ${ }^{1}$
}

\author{
${ }^{1}$ University of Belgrade - Faculty of Pharmacy, Department of Medical Biochemistry, \\ Belgrade, Serbia \\ ${ }^{2}$ University of Belgrade - Faculty of Medicine, Department of Cardiology, University \\ Medical Center "Bežanijska kosa", Belgrade, Serbia \\ ${ }^{3}$ Department of Pulmology, University Medical Center "Bežanijska kosa”, \\ Belgrade, Serbia \\ ${ }^{4}$ Department of Laboratory Diagnostics, University Medical Center "Bežanijska kosa", \\ Belgrade, Serbia
}

*Corresponding author: Ana Ninić, e-mail: aninic@ pharmacy.bg.ac.rs

\begin{abstract}
Obstructive sleep apnea (OSA) as a worldwide prevalent condition carries risk for cardiovascular and metabolic diseases, ultimately increasing overall mortality rates. Nonalcoholic fatty liver disease (NAFLD) can be considered as the primary metabolic disease, but also as a coexisting OSA comorbidity. Although prevalence of NAFLD covers quarter of world population, it increases with OSA presence. It can be speculated that chronic intermittent hypoxia (CIH) and sympathetic nervous system overactivity are involved in NAFLD pathogenesis and progression from simple steatosis through steatohepatitis to fibrosis. CIH provides the environment for liver oxidative stress, inflammation and increases the expression of genes involved in cholesterol and fatty acids synthesis. Catecholamines increase $\beta$-oxidation in liver and release free fatty acids from adipose tissue in plasma which inhibit insulin effects. Obesity and insulin resistance as key players in NAFLD development and advancement, deepen vicious circle of oxidative stress, inflammation and dyslipidemia. If not treated, OSA in NAFLD patients has been associated with inflammation, hepatocytes' necrosis, and fibrosis. Continuous positive airway pressure (CPAP) represents gold standard for OSA therapy, allowing the unimpeded air passage through upper parts of respiratory system. However, it has been demonstrated that CPAP therapy have beneficial effects on cardiometabolic outcomes and slow liver degeneration.
\end{abstract}

Key words: obstructive sleep apnea, chronic intermittent hypoxia, non-alcoholic fatty liver disease, fibrosis

DOI: https://doi.org/10.5937/arhfarm70-27586 


\section{Obstructive sleep apnea (OSA)}

Obstructive sleep apnea (OSA) is characterized by the partial (hypopnea) or complete (apnea) cessation of the air passage through the upper parts of the respiratory system, which occurs due to the collapse of the pharynx during sleep (1). Anatomic (enlarged tonsils, tongue volume, pharynx lateral walls, and maxilla abnormal positioning) and neuromuscular factors (reduced pharynx neuromuscular activity and pharyngeal dilator muscle hypotonia) mainly participate in the collapse of the pharyngeal soft structures. Due to the reduced respiratory muscle tone, there is also a reduced ventilation volume during sleep. Low respiratory volume and minute ventilation cause a decrease in the partial pressure of oxygen in the blood (hypoxemia), and an increase in the partial pressure of carbon dioxide in the blood (hypercapnia) (1). The other consequences of this condition are variations in intrathoracic pressure, chronic intermittent hypoxia $(\mathrm{CIH})$, sleep fragmentation, and chronic daytime sleepiness. However, the prevalence of OSA worldwide increases with obesity (2). This condition is a risk factor for endothelial dysfunction, atherosclerosis, and cardiovascular diseases (hypertension, arrhythmia, stroke, coronary heart disease) (3). Also, it is in tight linkage with insulin resistance and type 2 diabetes mellitus (4), non-alcoholic fatty liver disease (NAFLD) (5), and dyslipidemia (6). OSA is more frequent in males, older age, individuals with larger neck circumference, and in cigarettes, and alcohol consumers (7-9).

Several recent studies have indicated that the prevalence of the disease is between 4-24\% for men and 2-9\% for women (10). Approximately 1 in 5 adults has a mild form of OSA, and 1 in 15 has a moderate or severe form (10) when the severity of OSA is assessed by the apnea-hypopnea index (AHI) which is defined by the number of objectively registered apnea or hypopnea interruptions of breathing per hour during sleep (1). Close to $70 \%$ of OSA patients are obese (11).

\section{Non-alcoholic fatty liver disease (NAFLD)}

NAFLD is one of the most common liver diseases comprises of a wide range of histopathological changes in the liver (12). The disease progresses during a longer period from simple steatosis (the triglycerides accumulation in lipid droplets within hepatocytes) through hepatocellular injury and lobular inflammation (non-alcoholic steatohepatitis or NASH), fibrosis, and ultimately to liver cirrhosis which could potentially lead to hepatocellular carcinoma (HCC) (13). NAFLD is a complex and multifactorial disease. Different suggestions had been proposed, but the widely accepted hypothesis for NAFLD development was the "two hits hypothesis". The "first hit" occurs due to the presence of obesity and insulin resistance leading to an accumulation of triglycerides and the appearance of steatosis. This potentiates further insults of the liver by the "second hit" which comprises activated pro-inflammatory pathways, mitochondrial dysfunction, and oxidative stress further causing chronic hepatic inflammation (steatohepatitis) and 
fibrogenesis (13). This seemed quite a simple scenario for such a complex disease. Recently, the "two hits hypothesis" was replaced by the "multiple hits hypothesis" suggesting that many factors acting solely and in a synergistic manner with each other by different cellular signalling pathways predispose NAFLD development and progression from steatosis to fibrosis (14).

Although insulin resistance is a key player in NAFLD development many other factors could initiate and potentiate its development and progression such as obesity, diet, gut microbiota, genetic and epigenetic factors as well as OSA $(13,14)$. NAFLD is also closely related to type 2 diabetes mellitus, metabolic syndrome, cardiovascular diseases, and chronic kidney disease (15). The most studied NAFLD risk factors are displayed in Figure 1. In many individual cases, NAFLD could progress to chronic liver disease.

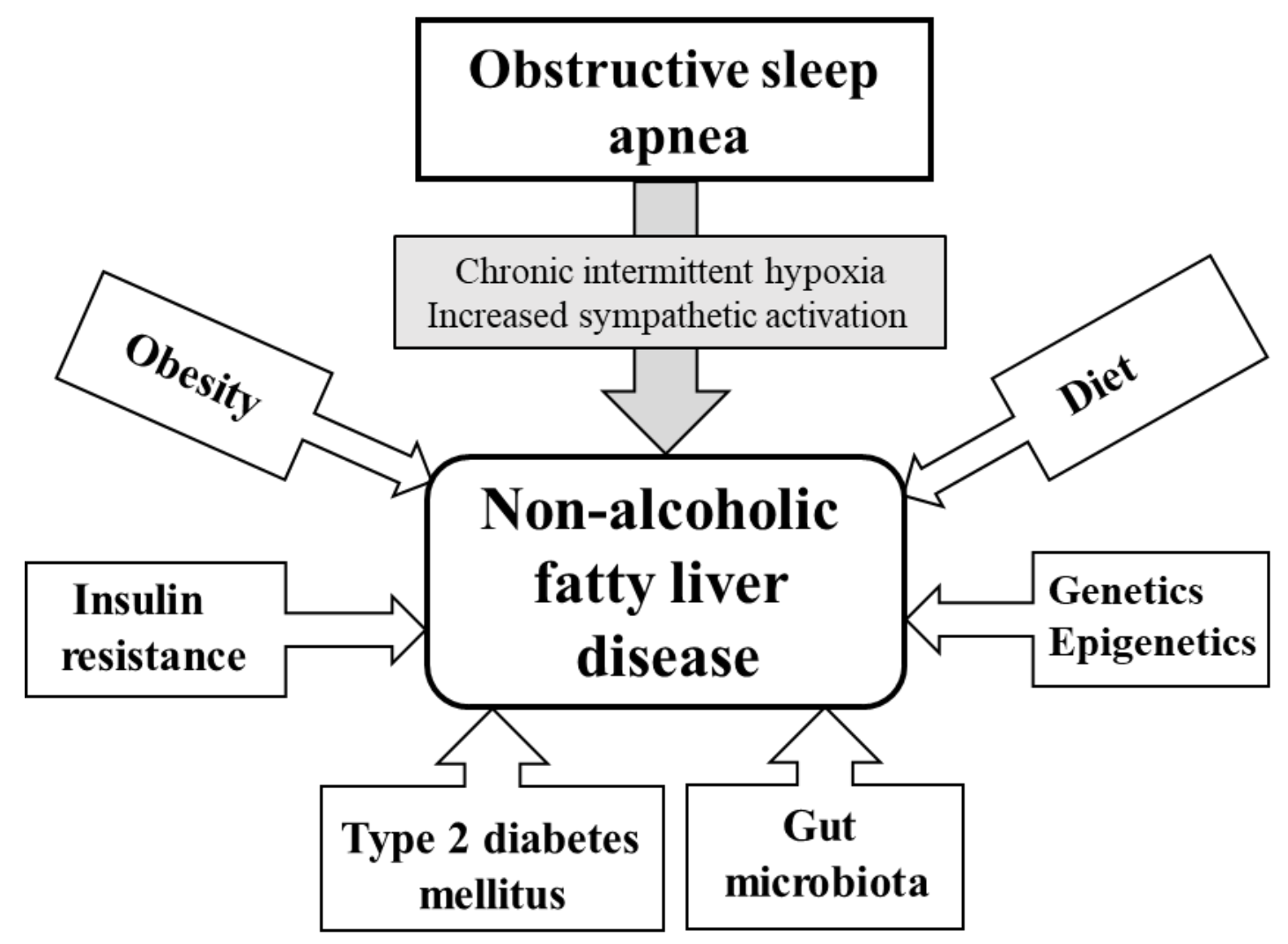

Figure 1. Risk factors associated with non-alcoholic fatty liver disease

Slika 1. Faktori rizika koji su povezani sa bolešću nealkoholne masne jetre 
Therefore, NAFLD represents a global burden to public health in developed and developing countries (12). NAFLD prevalence of $25 \%$ has been documented in the European population. $60 \%$ to $75 \%$ of NAFLD patients are obese. Alarming data published in a recent meta-analysis indicated an increase in NAFLD prevalence in children and adolescents. NAFLD had $7.6 \%$ of children in the general population with an increased rate of up to $34.2 \%$ in obese. Close to $10 \%$ of patients with simple steatosis progress to the more severe form, NASH, and $20 \%$ of them to HCC. Patients with NAFLD have no or nonspecific symptoms (12). Biochemistry testing of the liver's enzyme profile, especially when aminotransferase activities are elevated could be the indication for liver ultrasound examination for detection of possible steatosis $(13,14)$. However, neither ultrasound nor high aminotransferase activities could differentiate simple steatosis from NASH and even those with advanced fibrosis. Alanine aminotransferase (ALT) is usually elevated in progression from steatosis to steatohepatitis, but normal ALT activities do not exclude either steatosis or NASH. When steatosis and NASH are present, the aspartate aminotransferase (AST)/ALT ratio is typically less than 1 (16). The fibrosis staging without biopsy could be performed using fibrosis 4 (FIB-4) index (17) (calculation includes age, ALT, AST, and platelet count) and BARD score (calculation includes body mass index, diabetes, AST, and ALT) (18). AST-to-platelet ratio can be applied for predicting fibrosis and cirrhosis (19). The gold standard diagnostic method for NAFLD is a liver biopsy. Although it is the most reliable method when performed by an experienced doctor, it has significant shortcomings such as invasiveness, bleeding, pain, infection and in a small percentage even lethal outcome. Therefore, various scoring systems for diagnosis and prognosis of NAFLD are increasingly used to replace liver biopsy (20).

\section{Chronic intermittent hypoxia - central event of cardiometabolic disturbances in OSA}

Definite mechanisms by which OSA leads to cardiometabolic disturbances are not completely elucidated. The main role could be probably assigned to $\mathrm{CIH}$ linking OSA to the development and advancement of dyslipidemia, inflammation, and oxidative stress (21).

Prolonged intermittent hypoxia, which can be measured as reduced peripheral oxyhemoglobin saturation, induces recurrent hypoxic and reoxidation states in blood and tissues. Such repetitive cycles cause the development of oxidative stress, which further interfere with organs and cell functions and metabolism. Oxidative stress is worsened by an increased sympathetic activation induced by negative intrathoracic pressure and recurrent awakenings during sleeping. Oxidative stress causes lipid peroxidation, protein, and deoxyribonucleic acid damage leading to cell apoptosis and necrosis. Furthermore, oxidative stress induces low-grade systemic inflammation by increasing the production 
of pro-inflammatory adipocytokines, adhesion molecules, and procoagulants $(22,23)$. An inflammatory response occurs due to the activation of the transcription factor nuclear factor (NF)-kB, which stimulates pro-inflammatory genes expression such as interleukin (IL)-1, IL-6, IL-8, tumour necrosis factor- $\alpha$ (TNF- $\alpha$ ), resistin, etc. from circulating monocytes (23) and macrophages (including Kupffer cells). Indeed, not only Kupffer cells but also hepatocytes in acute liver injury synthesize IL-6 to establish normal hepatic function and to induce production of acute-phase proteins (24). However, in the chronic course of OSA, IL-6 in an autocrine and paracrine manner maintains inflammation (25). $\mathrm{C}$ reactive protein (CRP) which is a significant serum marker of inflammation, together with IL-6 reflect the degree of the inflammatory response $(25,26)$.

$\mathrm{CIH}$ via oxygen responsive hypoxia-inducible factor 1 (HIF-1) induces expression of key transcriptional factors and enzymes involved in lipid metabolism such as sterol regulatory element-binding protein 1 (SREBP-1), stearoyl-coenzyme A desaturase 1 (SCD-1), and fatty acid synthase (27). SREBP1 transcription factor increases the synthesis of triglycerides, phospholipids, and fatty acids. SCD-1 converts saturated to monounsaturated fatty acids which, when increased, lead to a higher synthesis of cholesterol esters and triglycerides. Increased numbers of very-low-density lipoprotein (VLDL) particles persist in the circulation. Due to the inhibition of lipoprotein lipase by $\mathrm{CIH}$, the clearance of chylomicrons and VLDL particles is decreased and their levels in circulation rise. Oxidative stress present in OSA leads to oxidative modification of lipoproteins making them more resistant to clearance from the bloodstream and more proatherogenic (28). Activated sympathetic nervous system via catecholamines increases lipolysis by activating hormone-sensitive lipase in adipose tissue and the efflux of free fatty acids in the circulation. Excess amounts of free fatty acids metabolites (acylcoenzyme A and diacylglycerol) in the liver and skeletal muscles inhibit the effects of insulin on glucose uptake and on glycogen synthesis (29). Even more, they express a harmful influence on the pancreas to release an insufficient quantity of insulin to counteract hyperglycemia $(15,29)$. This scenario includes both, peripheral and hepatic insulin resistance.

\section{Physiopathology link between OSA and NAFLD}

The liver has a double blood supply, by hepatic artery and portal vein. Hepatocytes close to the portal triad receive blood rich in oxygen and are involved in oxidative metabolism, bile, and glucose syntheses (30). Hepatocytes close to the central vein have poor oxygen supply, mediate glucose uptake and glycogen synthesis. This makes the liver sensitive not only to hypoxemia present in OSA but to oscillations in oxygen supply, especially its periportal zones $(30,31)$.

Many studies were conducted to establish potential associations between elevated aminotransferases levels and the severity of OSA. As liver-specific enzyme ALT was 
affected only by a severe form of OSA, but not by mild and moderate. AST, however, showed no association with OSA status (32). Norman and colleagues demonstrated that lower oxygen saturation levels (below 90\%), but not AHI, were independently related to higher AST and ALT levels (33). In the other study, only AHI greater than 50 was a stronger predictor for elevated liver enzymes than body mass index (34). The rise of hepatocytes cytosolic enzymes in plasma (ALT and AST), could signify plasma membrane damage, the release of enzymes in blood, and consequently cell apoptosis $(16,30)$.

OSA was significantly associated with hepatocytes' ballooning, lobular inflammation, and fibrosis (32). AHI was a significant positive predictor for fibrosis progression independently of obesity and diabetic status (35). Except for AHI, the duration of nocturnal hypoxia was also highly associated with NAFLD severity (36). Aminoterminal peptide procollagen type 3 as a serum marker of fibrosis was associated negatively with oxygen saturation during sleep and positively with AHI and visceral fat, indicating realistic risk for steatohepatitis development, especially in those with hepatic steatosis (37). According to this, not only the association but NAFLD deterioration from simple steatosis to lobular inflammation and fibrosis occurs in OSA patients. The role of obesity connecting OSA and NAFLD should not be neglected. Some authors have found that only in morbidly obese patients diagnosed with OSA, the progression of steatosis to NASH was evident (36). However, when both present, OSA and obesity jointly stimulate NAFLD progression $(29,35,36)$.

\section{Pathophysiologic mechanisms linking OSA and NAFLD are still not completely clarified.}

$\mathrm{CIH}$ is an initiator of the vicious circle of oxidative stress, low-grade systemic inflammation, and dyslipidemia, processes that are basically present in the progression of NAFLD (1,13). On the other hand, insulin resistance as a crucial feature of NAFLD stimulates oxidative stress, inflammation, and lipotoxicity (14). Worsening of steatosis in OSA happens in conjunction of three processes: increased lipolysis in adipose tissue, increased lipid synthesis in the liver, and decreased clearance of lipoproteins from circulation (28). Lipolysis of triglycerides into free fatty acids and glycerol in adipose tissue stimulated by overactive sympathetic nervous system induces VLDL synthesis in the liver. If not incorporated in VLDL, free fatty acids undergo $\beta$-oxidation, a metabolic process highly activated in insulin resistance state and cause overproduction of reactive oxygen species which further exacerbate liver oxidative stress (22). Lipotoxicity drives mitochondrial and endoplasmic stress, cellular injury and hepatocellular apoptosis, and necrosis. Under these circumstances, hepatic stellate cells actively synthesize collagen and other components of the extracellular matrix (elastin, proteoglycans, hyaluronic acid, fibronectin, etc) as a healing process (38). In acute hypoxic damage, apoptotic and necrotic cells are replaced with regenerated hepatocytes. But, in chronic liver injury 
probably occurring in OSA, hepatic stellate cells are being activated and transformed into myofibroblasts with proinflammatory and fibrogenic properties. Hepatic stellate cell activation happens by inflammatory mediators secreted from Kupffer cells, monocytes, platelets, etc., and initiates large amounts of high-density extracellular matrix deposition interfering with hepatocytes' metabolic functions (39).

$\mathrm{CIH}$ induces adipose tissue low-grade inflammation and leads to imbalanced production of proinflammatory and anti-inflammatory adipocytokines in favour of the former (21). Furthermore, it is assumed that hypoxia in adipose tissue induces inhibition of adipogenesis and triglyceride synthesis. In this manner obesity and OSA synergistically cause adipocytes death and further deepen insulin resistance, local and systemic inflammation (40). Leptin, a hormone secreted by adipocytes, stimulates collagen, and tissue inhibitor of metalloproteinase 1 expression in hepatic stellate cells (41). It also activates liver macrophages or Kupffer cells to produces profibrogenic stimulators, transforming growth factor $\beta$ (TGF- $\beta$ ) family members which have roles in progression from steatosis to steatohepatitis and fibrosis. Although the main effector for hepatic stellate cell activation is a platelet-derived growth factor, TGF- $\beta$ family members mediate an epithelial-mesenchymal transition process in hepatocytes that contribute directly to hepatic stellate cells to transform into myofibroblasts and produce large amounts of extracellular matrix (42). The other adipocytokines also demonstrate a disturbed expression profile in the blood due to NAFLD progression. Contrary to leptin, levels of adiponectin produced by adipocytes decrease with NAFLD advancement (43). As well, its beneficial properties such as anti-inflammatory, anti-steatosis, and insulinsensitizing on liver functions and structure weaken. Lower adiponectin levels were related to the severe fibrosis stage, lobular or portal inflammation, even HCC. However, due to delayed and lower adiponectin clearance by the liver, in the end stage of liver disease (cirrhosis), its levels increase. Additionally, $\mathrm{CIH}$ initiates multiple cellular signalling pathways in the liver and other tissues of which NF- $\kappa B$ is greatly important in NAFLD progression (44). Signalling cascade through NF- $\kappa \mathrm{B}$ pathway includes activation of Kupffer and stellate cells to release inflammatory and fibrogenic mediators (23). This is a suitable millie for the fibrosis onset. Predominantly released from adipose tissue and smaller extent from the liver, retinol-binding protein (RBP) 4 positively correlates with histological liver impairment, hepatic lesions, and fibrosis (43). Visfatin as proinflammatory adipokines produced by various tissues mainly regulates cells' proliferation and glucose homeostasis. It adversely affects glucose metabolism in pancreas $\beta$-cells and liver, consequently insulin resistance. It stimulates hepatic steatosis and inflammation (43). IL-6, pleiotropic proinflammatory cytokine, produced by adipocytes, hepatocytes, immune and endothelial cells (45) positively correlates with the degree of inflammation, stage of fibrosis, and insulin resistance (25). Also, pro-inflammatory cytokines released from activated macrophages (IL-1, IL-6, TNF- $\alpha$, monocyte chemoattractant protein 1, resistin and others) additionally deepen liver inflammation and induce fibrotic 
derangements in it (32). All these processes are supported by constant delivery of free fatty acids from adipose tissue by portal circulation which stimulate triglyceride synthesis and their storage at the beginning and, as insulin resistance persisted, their lipolysis and $\beta$-oxidation $(28,29)$.

The potential role of gut microbiota linking OSA and NAFLD was assumed as detrimental factor for steatosis advancement. Chronic inflammation triggered by intestinal endotoxin (bacterial lipopolysaccharide) in conjunction with OSA disrupts intestinal mucosa integrity but also stimulates activation of hepatic stellate cells (14). However, nocturnal hypoxemia exacerbates chronic inflammation by activating the Tolllike receptor 4 (TRL 4) signalling pathway. In additive effect with endotoxin, OSAstimulated TLR 4 induces cytokines production by Kupffer cells, collagen synthesis by activated stellate cells, its deposition, and eventually hepatic fibrosis advancement (46).

\section{Effects of continuous positive airway pressure (CPAP) on NAFLD status}

Currently, the most effective therapy for OSA is non-invasive ventilation or continuous positive airway pressure (CPAP). CPAP application transfers the air through the upper parts of the respiratory tract under a higher pressure than the atmospheric using a nasal or oronasal mask during sleeping (47). CPAP increases intraluminal air pressure and prevents airway collapse which underlies the OSA development. Also, CPAP increases the lung volume at the end of expiration, strengthens the pharyngeal wall, and contributes to the improvement of dilator muscle function. All of these improve oxyhemoglobin saturation and lowers oxidative stress indicating the basis for the favourable environment for better life quality and cardiometabolic state improvement (47). Generally observed in so far published papers, data were controversial in obese and non-obese individuals as well as in diabetic and non-diabetic ones, respectively using CPAP therapy (48). Insulin resistance and metabolic status were improved remarkably in OSA non-diabetic and non-obese patients compared to diabetic and obese, indicating significant effects not only of OSA but obesity on their development (48). Conflicting data were also published about weight loss when CPAP therapy is applied (49,50). Still, in mutual effects with different reducing weight protocols, CPAP could ameliorate OSA status, its cardiometabolic outcomes, and slow the progression of NAFLD (50).

CPAP therapy during a couple of months showed beneficial effects on liver enzymes status in adults and children (50). The serum ALT levels gradually decreased when compared in patients with severe OSA, moderate and mild OSA on adherent CPAP therapy (49). The same occurred for AST levels. The opposite was shown after 4 weeks of CPAP therapy. No beneficial effects on aminotransferase levels were observed in the study by Kohler's team (51). Besides, the AST-to-platelet ratio, as a determinant of advanced fibrosis, was significantly reduced in patients with good compared to those with 
partial or poor CPAP adherence (52). Advanced fibrosis bears high mortality risk and CPAP could have a pivotal role to reduce overall mortality risk by improving fibrotic injuries. However, the other study determined no significant decrease in triglycerides content and hepatic steatosis after CPAP (51). Although inconsistent, modest favourable effects of CPAP were found on glucose and lipid levels in OSA patients (53). Using CPAP, a decrease in inflammation markers (IL-6, CRP TNF- $\alpha$ ), oxidative stress (8-isoprostane), and coagulation factors (von Willebrand factor, factors V and VIII) was noted (54). It is more likely that liver enzymes status and fibrotic liver damages improve with long term adherent CPAP (51). Also, long-term CPAP could ameliorate deleterious progression from steatosis to steatohepatitis especially when all cardiometabolic markers are improved (50).

\section{Conclusion}

The pathogenesis of NAFLD is undoubtedly complex and likely involves a complex interplay between environmental and genetic factors. It can develop solely as a hepatic manifestation of insulin resistance. However, as a comorbid state, NAFLD shares metabolic derangements with many other diseases and one of them is OSA. CIH as a hallmark of OSA links it to dysregulation of glucose and lipid metabolism, oxidative stress, and hepatic inflammation, all of which presents basic features of NAFLD development and exacerbation. With the fact that both conditions, OSA and NAFLD are highly prevalent in the modern world as global health burden and risk factors for cardiovascular disease, it is recommended that all patients with NAFLD should be subjected to polysomnographic testing. Still, more well-controlled studies are emerged to investigate the relationship and causality between these two conditions, as well as randomised clinical trials to determine CPAP effects on NAFLD.

\section{Acknowledgement}

The work was financially supported by the Ministry of Education, Science and Technological Development of the Republic of Serbia (No. 451-03-68/2020-14/200161).

\section{References}

1. Dempsey JA, Veasey SC, Morgan BJ, O'Donnell CP. Pathophysiology of sleep apnea. Physiol Rev. 2010;90(1):47-112.

2. Young T, Peppard PE, Taheri S. Excess weight and sleep-disordered breathing. J Appl Physiol. 2005;99(4):1592-9. 
3. Baguet J-P, Barone-Rochette G, Tamisier R, Levy P, Pépin J-L. Mechanisms of cardiac dysfunction in obstructive sleep apnea. Nat Rev Cardiol. 2012;9(12):679-88.

4. Reutrakul S, Mokhlesi B. Obstructive sleep apnea and diabetes: A state of the art review. Chest. 2017;152(5):1070-86.

5. Aron-Wisnewsky J, Minville C, Tordjman J, Levy P, Bouillot JL, Basdevant A, et al. Chronic intermittent hypoxia is a major trigger for non-alcoholic fatty liver disease in morbid obese. $\mathrm{J}$ Hepatol. 2012;56(1):225-33.

6. Adedayo AM, Olafiranye O, Smith D, Hill A, Zizi F, Brown C, et al. Obstructive sleep apnea and dyslipidemia: evidence and underlying mechanism. Sleep and Breathing. 2014;18(1):13-8.

7. Young T, Peppard PE, Gottlieb DJ. Epidemiology of obstructive sleep apnea - A population health perspective. Am J Respir Crit Care Med. 2002;165(9):1217-39.

8. Wetter DW, Young TB, Bidwell TR, Badr MS, Palta M. Smoking as a risk factor for sleep-disordered breathing. Arch Intern Med. 1994;154(19):2219-24.

9. Scanlan MF, Roebuck T, Little PJ, Redman JR, Naughton MT. Effect of moderate alcohol upon obstructive sleep apnoea. Eur Respir J. 2000;16(5):909-13.

10. Young T, Peppard PE, Gottlieb DJ. Epidemiology of obstructive sleep apnea: a population health perspective. Am J Resp Crit Care. 2002;165(9):1217-39.

11. Resta O, Foschino-Barbaro MP, Legari G, Talamo S, Bonfitto P, Palumbo A, et al. Sleep-related breathing disorders, loud snoring and excessive daytime sleepiness in obese subjects. International journal of obesity. 2001;25(5):669-75.

12. Younossi Z, Anstee QM, Marietti M, Hardy T, Henry L, Eslam M, et al. Global burden of NAFLD and NASH: trends, predictions, risk factors and prevention. Nat Rev Gastroenterol Hepatol. 2018;15(1):11-20.

13. Hardy T, Oakley F, Anstee QM, Day CP. Nonalcoholic fatty liver disease: pathogenesis and disease spectrum. Annu Rev of Pathol-Mech. 2016;11:451-96.

14. Buzzetti E, Pinzani M, Tsochatzis EA. The multiple-hit pathogenesis of non-alcoholic fatty liver disease (NAFLD). Metabolism. 2016;65(8):1038-48.

15. Byrne CD, Targher G. NAFLD: a multisystem disease. J Hepatol. 2015;62(1):S47-64.

16. Sorbi D, Boynton J, Lindor KD. The ratio of aspartate aminotransferase to alanine aminotransferase: potential value in differentiating nonalcoholic steatohepatitis from alcoholic liver disease. Am $\mathbf{J}$ Gastroenterol. 1999;94(4):1018-22.

17. Sterling RK, Lissen E, Clumeck N, Sola R, Correa MC, Montaner J, et. al. Development of a simple noninvasive index to predict significant fibrosis patients with HIV/HCV co-infection. Hepatology 2006;43(6):1317-25.

18. Harrison SA, Oliver D, Arnold HL, Gogia S, Neuschwander-Tetri BA. Development and validation of a simple NALFD clinical scoring system for identifying patient without advanced disease. Gut. 2008;57(10):1441-47.

19. Lin ZH, Xin YN, Dong QJ, Wang Q, Jiang XJ, Zhan SH, et al. Performance of the aspartate aminotransferase-to-platelet ratio index for the staging of hepatitis C-related fibrosis: an updated meta-analysis. Hepatology. 2011;53(3):726-36.

20. Sumida Y, Nakajima A, Itoh Y. Limitations of liver biopsy and non-invasive diagnostic tests for the diagnosis of nonalcoholic fatty liver disease/nonalcoholic steatohepatitis. World J Gastroenterol. 2014;20(2):475-85. 
21. Drager LF, Jun JC, Polotsky VY. Metabolic consequences of intermittent hypoxia: relevance to obstructive sleep apnea. Best Pract Res Cl En. 2010;24(5):843-51.

22. Lavie L, Lavie P. Molecular mechanisms of cardiovascular disease in OSAHS: the oxidative stress link. Eur Respir J. 2009;33(6):1467-84.

23. Irwin MR, Wang M, Campomayor CO, Collado-Hidalgo A, Cole S. Sleep deprivation and activation of morning levels of cellular and genomic markers of inflammation. Arch Intern Med. 2006;166(16):1756-62.

24. Norris CA, He M, Kang LI, Ding MQ, Radder JE, Haynes MM, et al. Synthesis of IL-6 by hepatocytes is a normal response to common hepatic stimuli. PloS one. 2014:24;9(4):e96053.

25. Hammerich L, Tacke F. Interleukins in chronic liver disease: lessons learned from experimental mouse models. Clinical and experimental gastroenterology. 2014;7:297.

26. Kushner I, Samols D, Magrey M. A unifying biologic explanation for "high-sensitivity" C-reactive protein and "low-grade" inflammation. Arthrit Care Res. 2010;62(4):442-6.

27. Li J, Thorne LN, Punjabi NM, Sun C-K, Schwartz AR, Smith PL, et al. Intermittent hypoxia induces hyperlipidemia in lean mice. Circ Res. 2005;97(7):698-706

28. Mirrakhimov AE, Ali AM. Pathobiology of obstructive sleep apnea-related dyslipidemia: focus on the liver. International Scholarly Research Notices. 2013;2013. http://dx.doi.org/10.1155/2013/687069.

29. Boden G. Obesity, insulin resistance and free fatty acids. Curr Opin Endocrinol Diabetes Obes. 2011;18(2):139-43.

30. Dufour DR. Liver disease. In: Tietz textbook of clinical chemistry and molecular diagnostics. Burtis CA, Ashwood ER, Bruns DE authors. 5th edition Saunders, USA; 2012; p. 1637-82.

31. Jungermann K, Kietzmann T. Oxygen: modulator of metabolic zonation and disease of the liver. Hepatology. 2000;31(2):255-60.

32. Jin S, Jiang $\mathrm{S}, \mathrm{Hu} \mathrm{A}$. Association between obstructive sleep apnea and non-alcoholic fatty liver disease: a systematic review and meta-analysis. Sleep Breath. 2018;22(3):841-51.

33. Norman D, Bardwell WA, Arosemena F, Nelesen R, Mills PJ, Loredo JS, et al. Serum aminotransferase levels are associated with markers of hypoxia in patients with obstructive sleep apnea. Sleep. 2008;31(1):121-6.

34. Bhatt SP, Guleria R. Sleep apnea and fatty liver disease: The growing link and management issues. World Journal of Respirology. 2014;4(2):11-8.

35. Agrawal S, Duseja A, Aggarwal A, Das A, Mehta M, Dhiman RK, et al. Obstructive sleep apnea is an important predictor of hepatic fibrosis in patients with nonalcoholic fatty liver disease in a tertiary care center. Hepatol Int. 2015;9(2):283-91.

36. Polotsky VY, Patil SP, Savransky V, Laffan A, Fonti S, Frame LA, et al. Obstructive sleep apnea, insulin resistance, and steatohepatitis in severe obesity. Am J Respir Crit Care Med. 2009;179(3):228-34.

37. Tatsumi K, Saibara T. Effects of obstructive sleep apnea syndrome on hepatic steatosis and nonalcoholic steatohepatitis. Hepatol Res. 2005;33(2):100-4.

38. Iredale JP. Models of liver fibrosis: exploring the dynamic nature of inflammation and repair in a solid organ. J Clin Investig. 2007;117(3):539-48. 
39. Nallagangula KS, Nagaraj SK, Venkataswamy L, Chandrappa M. Liver fibrosis: a compilation on the biomarkers status and their significance during disease progression. Future Sci OA. 2017;4(1):FSO250. doi: 10.4155/fsoa-2017-0083.

40. Yin J, Gao Z, He Q, Zhou D, Guo Z, Ye J. Role of hypoxia in obesity-induced disorders of glucose and lipid metabolism in adipose tissue. Am J Physiol Endocrinol Metab. 2009;296(2):E333-E42.

41. Marra F. Leptin and liver tissue repair: Do rodent models provide the answers? J Hepatol. 2007;46(1):12-8.

42. Dewidar B, Meyer C, Dooley S. TGF- $\beta$ in Hepatic Stellate Cell Activation and Liver FibrogenesisUpdated 2019. Cells. 2019;8(11):1419 doi: 10.3390/cells8111419.

43. Polyzos SA, Kountouras J, Mantzoros CS. Adipokines in nonalcoholic fatty liver disease. Metabolism. 2016;65(8):1062-79.

44. Liu T, Zhang L, Joo D, Sun SC. NF-кB signaling in inflammation. Signal transduct tar. 2017;2: e17023; doi:10.1038/sigtrans.2017.23.

45. Liu T, Zhang L, Joo D, Sun SC. NF-кB signaling in inflammation. Signal transduct tar. 2017;2: e17023; doi:10.1038/sigtrans.2017.23.

46. Stojsavljević S, Gomerčić Palčić M, Virović Jukić L, Smirčić Duvnjak L, Duvnjak M. Adipokines and proinflammatory cytokines, the key mediators in the pathogenesis of nonalcoholic fatty liver disease. World j gastroentero. 2014;20(48):18070-91.

47. Akinnusi M, Jaoude P, Kufel T, El-Solh AA. Toll-like receptor activity in patients with obstructive sleep apnea. Sleep Breath. 2013;17(3):1009-16.

48. Loube DI, Gay PC, Strohl KP, Pack AI, White DP, Collop NA. Indications for positive airway pressure treatment of adult obstructive sleep apnea patients: a consensus statement," Chest. 1999;115(3): 863-6.

49. Levy P, Bonsignore MR, Eckel J. Sleep, sleep-disordered breathing and metabolic consequences. Eur Respir J. 2009;34(1):243-60.

50. Kim D, Ahmed A, Kushida C. Continuous positive airway pressure therapy on nonalcoholic fatty liver disease in patients with obstructive sleep apnea. J Clin Sleep Med. 2018;14(8):1315-22.

51. Aron-Wisnewsky J, Clement K, Pépin JL. Nonalcoholic fatty liver disease and obstructive sleep apnea. Metabolism. 2016;65(8):1124-35.

52. Kohler M, Pepperell JC, Davies RJ, Stradling JR. Continuous positive airway pressure and liver enzymes in obstructive sleep apnoea: data from a randomized controlled trial. Respiration. 2009;78(2):141-6.

53. Kim D, Kim WR, Kim HJ, Therneau TM. Association between noninvasive fibrosis markers and mortality among adults with nonalcoholic fatty liver disease in the United States. Hepatology. 2013;57(4):1357-65.

54. Xu H, Yi H, Guan J, Yin S. Effect of continuous positive airway pressure on lipid profile in patients with obstructive sleep apnea syndrome: a meta-analysis of randomized controlled trials. Atherosclerosis 2014;234(2):446-53.

55. Jin F, Liu J, Zhang X, Cai W, Zhang Y, Zhang W, et al. Effect of continuous positive airway pressure therapy on inflammatory cytokines and atherosclerosis in patients with obstructive sleep apnea syndrome. Mol Med Rep. 2017;16(5):6334-9. 


\title{
Bolest nealkoholne masne jetre kao metabolička posledica opstruktivne apneje u snu
}

\author{
Ana Ninić ${ }^{1 *}$, Marija Zdravković ${ }^{2}$, Vojislav Radosavljević ${ }^{3}$, \\ Vera Gardijan ${ }^{3}$, Lidija Memon ${ }^{4}$, Jelena Vekić ${ }^{\text {, }}$ \\ Vesna Spasojević- Kalimanovska ${ }^{1}$
}

\author{
${ }^{1}$ Univerzitet u Beogradu - Farmaceutski fakultet, Katedra za medicinsku biohemiju, \\ Beograd, Srbija \\ ${ }^{2}$ Univerzitet u Beogradu - Medicinski fakultet, Odeljenje kardiologije, Kliničko-bolnički \\ centar „Bežanijska kosa”, Beograd, Srbija \\ ${ }^{3}$ Odeljenje pulmologije, Kliničko-bolnički centar „Bežanijska kosa”, Beograd, Srbija \\ ${ }^{4}$ Služba laboratorijske dijagnostike, Kliničko-bolnički centar „Bežanijska kosa”, \\ Beograd, Srbija
}

*Autor za korespondenciju: Ana Ninić, e-mail: aninic@ pharmacy.bg.ac.rs

\begin{abstract}
Kratak sadržaj
Opstruktivna apneja u snu (OSA) kao oboljenje prevalentno u svetu nosi rizik za nastanak kardiovaskularnih i metaboličkih bolesti, povećavajući ukupnu smrtnost. Bolest nealkoholne masne jetre (eng. non-alcoholic fatty liver disease - NAFLD) se može smatrati primarnom metaboličkom bolešću, ali kao i komorbiditet OSA. Iako prevalenca NAFLD obuhvata četvrtinu svetske populacije, ona se povećava sa prisustvom OSA. Pretpostavlja se da su hronična intermitentna hipoksija (eng. chronic intermittent hypoxia - $\mathrm{CIH}$ ) i prekomerna aktivnost simpatičkog nervnog sistema uključeni u patogenezu NAFLD i progresiju od steatoze preko steatohepatitisa do fibroze. U jetri CIH stvara uslove za oksidativni stres, inflamaciju i povećava ekspresiju gena koji učestvuju u sintezi holesterola i masnih kiselina. Kateholamini stimulišu $\beta$ oksidaciju masnih kiselina u jetri i oslobađaju slobodne masne kiseline iz masnog tkiva u plazmu, koje inhibiraju dejstva insulina. Gojaznost i insulinska rezistencija kao ključni faktori u razvoju i napredovanju NAFLD produbljuju začarani krug oksidativnog stresa, inflamacije i dislipidemije. Ako se ne leči, OSA kod pacijenata sa NAFLD je povezana sa inflamacijom, nekrozom hepatocita i fibrozom. Kontinuirani pozitivni pritisak vazduha (eng. continuous positive airway pressure CPAP) predstavlja zlatni standard u terapiji OSA, koji omogućava neometani prolaz vazduha kroz gornje delove respiratornog sistema. Međutim, CPAP terapija je pokazala da ima povoljne efekte na kardiometaboličke ishode i da usporava degeneraciju jetre.
\end{abstract}

Ključne reči: opstruktivna apneja u snu, hronična intermitentna hipoksija, bolest nealkoholne masne jetre, fibroza 